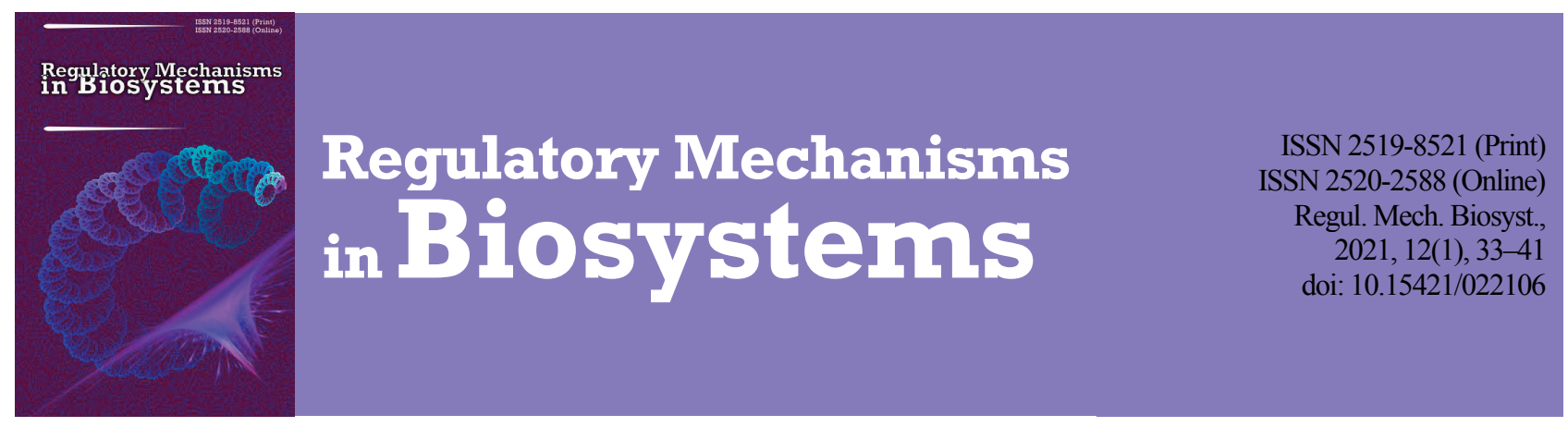

\title{
Genetic variability and biodiversity of Ukrainian Gray cattle by the BoLA-DRB3 gene
}

\author{
T. M. Suprovych*, M. P. Suprovych*, N. B. Mokhnachova**, O. D. Biriukova**, L. V. Strojanovska*, V. A. Chepurna* \\ *Podillia State University, Kamianets-Podilskyi, Ukraine \\ **Institute of Animal Breeding and Genetic, NAAS of Ukraine, Chubynske, Ukraine
}

Article info

Received 29.01.2021

Received in revised form 05.03 .2021

Accepted 06.03.2021

Podillia State University, Shevchenko, 13,

Kamianets-Podilskyi

32300, Ukraine.

Tel.: +38-098-576-30-18.

E-mail:

suprovycht@gmail.com

Institute of Animal

Breeding and Genetic,

NAAS of Ukraine,

Pogrebniaka, 1,

Chubynske, 08321, Ukraine.

Tel. +38-068-126-49-58.

E-mail:

irgt.spetsrada@ukr.net

Suprovych, T. M., Suprovych, M. P., Mokhnachova, N. B., Biriukova, O. D., Strojanovska, L. V., \& Chepurna, V. A. (2021). Genetic variability and biodiversity of Ukrainian Gray cattle by the BoLA-DRB3 gene. Regulatory Mechanisms in Biosystems, 12(1), 33-41. doi:10.15421/022106

At the current stage of genetic studies of cattle, more and more attention is being drawn to autochthonous breeds. Native cattle have a number of prominent phenotypic traits and have preserved unique genes and their combinations lost by modern commercial breeds, which would be valuable to use in selective programs. We surveyed polymorphism of the Ukrainian autochthonous Gray breed according to alleles of exon 2 of the BoLA-DRB3 gene. The uniqueness of the gene lies in the broad variability of its allele variants. Significant informativeness at DNA level is quite important for genetic studies. We surveyed allele polymorphism using the PCR-RLFP method on DNA isolated from 88 samples of blood of cows and 5 samples of sperm. We identified 28 alleles, of which 23 variants were nomenclature ones and 5 (jba, *jab, *jbb, *nad and *nda) were "without established nomenclature", their share accounting for $8.9 \%$. Four alleles $* 06, * 12, * 16$ and $*$ jba had a frequency above $5 \%$ and occupied $69.9 \%$ of the breed's allele fund overall. The commonest allele was BoLA-DRB3.2*16 (44.1\%). In total, we found 40 genotypes. Considering the significant dominance of variant $* 16$, as expected, 5 genotypes with its inclusion occurred: *16/*16,*12/*16, *06/*16, *16/*24 and *jba/*16. It was present in the genotype of two out three studied animals. Parameters of heterozygosity, effective number of alleles, Shannon and Pielou indices indicate that Ukrainian Gray cattle are characterized by lowest level of genetic variability and biodiversity according to the BoLA-DRB3 gene compared with other breeds. Due to significant dominance of allele *16, the breed has no inbred motifs. We noted deviation toward increase in homozygosity without deviations from the norm of the distribution according to Hardy-Weinberg equilibrium. The obtained results will be used for genetic-populational programs with the purpose of improving the genetic potential of cattle breeds in terms of economically beneficial traits and diseases of cattle.

Keywords: autochthonous breed; polymorphism; PCR-RLFP; BoLA-DRB3 gene; consolidating and significance alleles.

\section{Introduction}

Diversity of living organisms is determined by the fundamental properties of biological macromolecules, especially nucleic acids, their property to spontaneously undergo changes in structure, leading to changes in genomes, and inherent variability. On this biochemical basis, diversity is the result of three separately acting processes: mutations, natural selection, geographic and reproductive isolation. These processes, in turn, lead to consequent taxonomic and ecological differentiation at all the following levels of biological ecosystems: species, coenotic and ecosystemic. Lately, humans have been actively interfering in these ecosystems, causing some species to be become extinct. Regular extinctions of cattle breeds are considered the main cause of loss of genetic diversity affecting agricultural animals (Scherf, 2000).

A relevant problem of contemporary cattle breeding is preservation and rationalization of using the gene fund of existing cattle breeds (Moiseeva et al., 2006). Special attention is paid to autochthonous breeds characterized by high adaptive properties, diversity of intrinsic benefits, undamaged balance in the system of genotype-environment and resistance to local pathogens, making the breeds highly resistant to diseases. Indigenous animals are highly valued as carriers of specific gene fund and unique genetic blocks that provide development of economically beneficial traits, lost by modern highly productive breeds. Expansion of the range of commercial breeds leads to steep decrease and total extinction of low-number native breeds, and therefore loss of unique genes and their combinations developed over prolonged use in agriculture and influence of natural factors (Stolpovskij et al., 1998; Guzjejev, 2014).
Ukrainian Gray cattle are one of the oldest indigenous breeds in Ukraine, characterized by highly valuable agricultural-biological traits: high resistance to diseases and extreme environmental factors, while being undemanding to the conditions of maintenance and feeding, strength of constitution, long period of productive use, high content of fat and protein in milk, high fat and meat parameters, high quality of meat (Kozyr, 2006). The animals have strong well-proportioned bodies, long life expectancy, and are adapted to the conditions of the steppe. A distinctive property of the breed is the high fertility of the cows. Birth of calves per 100 cows has for many years remained at the level of $90-99 \%$. It is a natural native gene fund object which is now at the brink of disappearance, and which has received the status of the first category of protection (Fig. 1).

Conservation of a breed is impossible without complex systems of monitoring, assessment and prediction of changes in genetic structure of the populations. Regarding this aspect, the genetic variability provided by diversity of genes related to the development of the agriculture-beneficial traits deserves the greatest attention. The necessary condition of evolution is existence of genetic variability. Genetic diversity is variation of genes inside a population. It lies in the changes in the sequence of four pairs of DNA bases and constitutes a genetic code. New genetic variability is created by mutations of genes and allows populations to adapt to variable conditions of environment.

Loss of genetic diversity as a result of long depression of number of the animals and malfunctioning of the mechanism of preservation of biological diversity in low-number populations is one of the most important problems in modern nature-protection biology. Populations with insignificant genetic variability are more vulnerable to new pests or diseases, envi- 
ronmental pollution, changes in climate and environment caused by the destructive activities of humans or other catastrophic events (Yuhki \& O'Brien, 1990). Genetic diversity to a large extent reflects the adaptive potential of organisms, populations and species (Fox \& Reed, 2011). This is related to variety of functionally important genes and gene complexes responsible for resistance of animals to unfavourable environmental factors infectious agents, various climate changes, etc. Therefore, researchers pay special attention to the genes of the major histocompatibility complex (MHC) responsible for the immunity. There are persuasive evidences that MHC polymorphism is driven by one or the other form of overdominance or balancing selection (Hughes \& Nei, 1989).

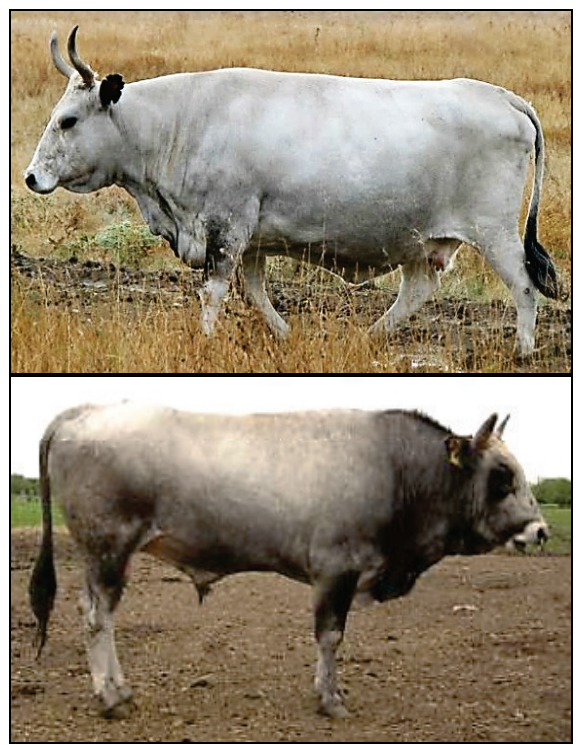

Fig. 1. Ukrainian Gray cattle

The species Bos taurus, to which cattle belong, has MHC genes located on the 23d chromosome (Fries et al., 1993). The major histocompatibility complex in cattle is known as the bovine leukocyte antigen (BoLA). It is a relatively large cluster of genes (multigene family) spanning nearly $2.5 \mathrm{Mb}$ of cattle genome. It is divided into three classes: the first is responsible for immunity to intracellular parasites (of both viral and bacterial origin), the second one for susceptibility to extracellular alien agents, and the third class of genes provides assistance to the first two classes (Mota et al., 2004; Behl et al., 2014).

Within the area of class II, two subclasses are designated - IIa and Ilb. Subgroup of class IIa contains functionally expressed genes DR and DQ. Genetic products of molecules DR and DQ are the main restrictive elements of class II for CD4 T-helper cells (Glass et al., 2000).

Cattle have three DRB genes, among which only one, DRB3, is considered functionally important. It is the most polymorphic locus of II class in cattle and affects both size and epitope specificity of antigen-specific T-cellular reaction to infectious diseases. The BoLA-DRB3 gene encodes antigen of II class of MHC of cattle. It is located on the outer side of the membrane of B-lymphocytes in the area of the IIa sublocus of the DR system. The main locus is exon 2 of BoLA-DRB3 that encodes $\beta 1$-domain of antigen of II class with broad variable structure of the grooves as a receptor to alien antigens. It is extremely polymorphic, and this polymorphism is carried out mostly in residues of peptide-binding grooves (Brown et al., 1993; Park et al., 1995).

Intensification of livestock breeding requires further development of the theoretic basis and improvement of organizational forms of selection of agricultural animals by employing new methods of assessment of their genetic structure, the main of which are various types of molecular markers. At the current stage of scientific research, studying biodiversity at the genetic level is impossible without them. Analysis of genetic variability using molecular technologies reveals data at the level of DNA. The keys in such research are the molecular markers that reflect polymorphism at DNA level. Such markers should be informative and take into account the level of complexity of typing, because experimental selections include a large number of animals.
For cattle research, various genetic markers are proposed (Singh et al., 2014). If the occurrence of a variant of a gene (allele) is found to be statistically significant in connection to some feature (disease, productivity, etc.), in this case one then may state a genetic-conditioned association of allele-trait or presence of its genetic marker.

Among the whole variety of genetic markers, the BoLA-DRB3 gene is unique. Its polymorphism is related to formation of immune response of the organism to viral and bacterial infections, and first of all is relevant for analysis of problems of resistance to diseases. In is in this particular context that most researchers consider application of the BoLA-DRB3 gene.

Evolutionary processes in MHC have developed a number of unique peculiarities of exon 2 of this gene. It has the highest polymorphicity among all the studied loci of MHC. There are described 144 BoLADRB3 alleles for cattle and 303 subtypes are listed in the Immuno Polymorphism Database (IPD-MHC database: www.ebi.ac.uk/ipd/mhc/ group/BoLA).

Variability of MHC reflects evolutionary and adaptive processes inside and between the populations and is very convenient for studying a broad circle of open questions in evolutionary ecology and conservation (Sommer, 2005). The extremely high level of polymorphism in BoLADRB3 genes allows it to be used as a highly informative marker for studying genetic variability and biodiversity of cattle. Polymorphism of its alleles is crucial for vitality of populations and species undergoing prolonged and catastrophic decline in numbers. Biodiversity of cattle at the level of DNA sequence according to the BoLA-DRB3 gene has been analyzed for two dozen breeds of Bos taurus out of over 800 existing. The main surveys in this direction belong to the group of researchers with participation and leadership of S. N. Takeshima. They conducted studies on genetic diversity of more than ten breeds, particularly Japanese Shorthorn and Jersey (Takeshima et al., 2003), Japanese black and Holstein cattle in Japan (Miyasaka et al., 2011; Miyasaka et al., 2012), Philippine native cattle (Takeshima et al., 2014), South American Holstein cattle populations (Takeshima et al., 2015a), Chilean cattle (Takeshima et al., 2015b), South American Zebu cattle (Takeshima et al., 2018) etc.

Currently, the BoLA-DRB3 gene is becoming more widely used in the study of genetic diversity of native breeds: Kankrej Indian cattle (Behl et al., 2007), Sahiwal, Rathi and Hariana Indian breeds (Behl et al., 2009), Mongolian, Kalmyk and Yakut cattle breeds (Ruzina et al., 2010), Korean native cattle (Lee et al., 2012), Latin American creole cattle breeds (Giovambattista et al., 2013), Mexico creole cattle (Fernández et al., 2015), Myanmar cattle (Giovambattista et al., 2020), native Sudanese cattle from Taurine and Zebu breeds (Salim et al., 2020), Kostroma and Yaroslavl indigenous Russian cattle breeds (Lazebnaya et al., 2020) etc. However, there are many unstudied breeds, most of the Ukrainian breeds being in this category, including Ukrainian Gray cattle. Among domestic breeds, such a study has been carried out only for black-pied (black-and-white) dairy cattle (Suprovych et al., 2017a).

There is one more aspect interesting for researchers: due to their close localization to some productive loci, polymorphism of BoLA-DRB3 gene is associated with economically useful traits of the cattle (Sharif et al., 1999), in particularly dairy productivity (Starkenburg et al., 1997; Gladyr et al., 2012).

The Ukrainian Gray breed as a unique gene fund object is of great interest to researchers. There was conducted a large-scale study of the genetic structure of the breed according to various genetic markers. Contemporary studies of blood and milk revealed unusual genetic combinations in genotype, namely specific alleles in the groups of blood system B, rare intrinsic blocks of casein alleles of milk, found erythrocytes to have a variant of protein of phosphoglucomutase, and detected a new protein of post-transferase in the plasma. As marker systems, the genes beta-lactoglobulin (BLG), kappa-casein (CSN3), thyroglobulin (TG5), calpain (CAPN1 530), growth hormone (GH), microsatellite loci (BM2113 and TGLA 227), transferase (Tf), blood type, etc are used (Huzeyev et al., 2014; Bodnaruk et al., 2017; Suprovich \& Mokhnachova, 2017; Sydorenko \& Gyzieev, 2019).

In the study, we used the following definitions of varieties of breeds: autochthonous, native, indigenous breed is the one that has emerged and exists in the same territorial boundaries, has its own source origin, independent from external factors; a local, regional breed is breed artificially 
created by cross breeding of native breed with another one for establishment of a certain direction of productivity; a commercial breed is a numerous breed artificially created for achieving maximum productivity according to a particular economically useful trait (for example the Holstein breed was developed for maximum milk yield).

In this study, we demonstrated the results of studying polymorphism, parameters of genetic variability and biodiversity of an autochthonous Ukrainian breed according to alleles of the BoLA-DRB3.2 gene using the PCR-PLFP method.

\section{Materials and methods}

We hereby declare that all ethical standards have been respected in preparation of the submitted article. Permission to use animals was approved by the State Agrarian and Engineering University in Podilya in accordance with the European Convention for the Protection of Vertebrate Animals used for Experimental and Other Scientific Purposes.

The experimental work was carried out in 2015-2018 at the laboratory of the Institute of Animal Breeding and Genetics named after M. V. Zubets of the National Academy of Agrarian Science of Ukraine. There were studied 88 samples of vein blood of cows of the Ukrainian Gray breed from two farms - Markeievo State Research Enterprise of the Institute of Animal Husbandry of the Steppe Regions named after Ivanov "Askania Nova", NAASU (herd A, n=40) and the Polyvanivka State Enterprise of the SI Institute of Grain Crops, NAASU (herd B, $n=48$ ) and the samples of sperm of breeder bulls of this breed, kept in the Bank of Animals Genetic Resources of the Institute of Animal Breeding and Genetics named after M. V. Zubets, Chubunske (n=5, Fig. 2).

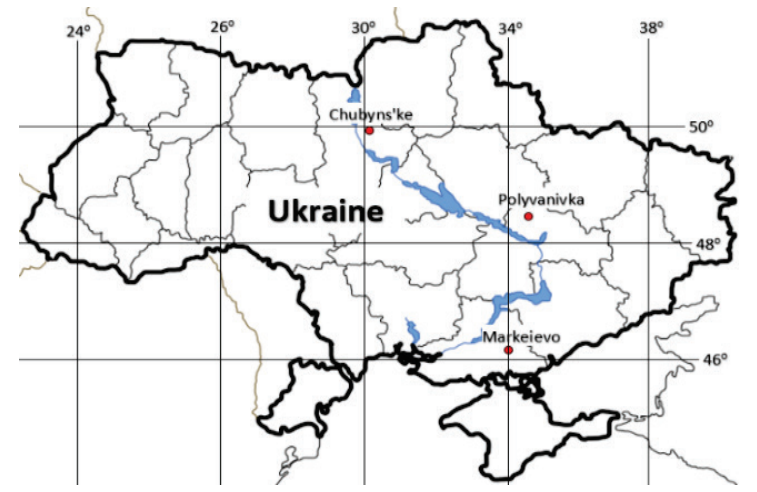

Fig. 2. Locations of research: Markeievo and Polyvanivka - farms of Ukrainian Gray cattle, Chubuns'ke - Bank of Animals Genetic Resources

Allele frequencies were determined based on the restriction analysis of polymorphism of products of amplification of exon 2 of BoLA-DRB3 gene (Sulimova, 2004).

PCR-RLFP technique belongs to enzymic methods of SNPs analysis (Single Nucleotide Polymorphism) and is similar to the RLFP method, though it is based on using PCR. Restrictions (using one or several restriction enzymes) in this case are applied to the products of amplification, but not genome DNA. Due to its simplicity and reliability, the method became broadly used for analysis of allele polymorphism of genes of various biological objects (Thiel, 2004; Al-Samarai \& Al-Kazaz, 2015).

Isolation of DNA from the samples of blood and sperm was made using standard commercial sets of DNA-sorb B manufactured by AmpliSens (Scientific Research Institute of Epidemiology, Moscow, Russia) according to the requirements of modified protocols using a set of reagents for isolating DNA from liquid blood and sperm respectively. Isolation of DNA from blood was performed using Chelex-100 ion-exchange resin according to the manual.

DNA isolated from pure biological material had high molecular mass (40-50 bp) and was pure substance $\left(\mathrm{OD}_{260 / 280} \mathrm{~nm}=1.6-2.0\right)$. Concentration and purity of DNA were measured using spectrophotometry and electrophoresis in 1\% agarose gel (Agarose, Biotechnology grade, and Helicon).

Amplification of exon 2 of BoLA-DRB3 was performed using PCR with ready-to-use sets manufactured by AmpliSens (Scientific Research
Institute of Epidemiology, Moscow, Russia) (Van Eijk et al., 1992). The total amount of the mixture $(20 \mu \mathrm{L})$ contained $60 \mathrm{mM}$ of Tris-HCL (pH 8.8), $2.5 \mathrm{mM}$ of $\mathrm{MgCl}_{2}, 20 \mathrm{mM}$ of $\mathrm{KCl}, 15 \mathrm{mM}$ of $\left(\mathrm{NH}_{4}\right)_{2} \mathrm{SO}_{4}$, $10 \mathrm{mM}$ of mercaptoethanol, $0.1 \%$ of Triton X-100, $0.2 \mathrm{mM}$ of dNTP, $10 \mathrm{U}$ of Klentaq DNA polymerase, $10 \mathrm{pM}$ of each primer, matrix DNA.

For the first round of reaction, we used the following primers: HLO30 (5'-3': TCCTCTCTCTGCAGCACATTTCC) and HLO-31 (5'-3': ATTCGCGCTCACCTCGCCGCT). As matrix, we used $5 \mu \mathrm{L}$ of DNA, regardless of concentration.

For the second round of PCR, we used primers: HLO-30 and HLO32 (5'-3': TCGCCGCTGCACAGTGAAACTCTC). Matrix was $2 \mu \mathrm{L}$ of PCR products of the first round.

PCR was carried out in Tertsia amplifier manufactured by the firm "DNA-technology". After the second round of well PCR, we performed electrophoresis in 1.8\% agarose for assessment of quality and concentration of the obtained fragment. No more than $3 \mu \mathrm{L}$ of sample were subjected to the gel. Products of PCR in the amount of $5 \mu \mathrm{L}$ were electrophoresed in $1.8 \%$ agarose gel in order to test the quality and specificity of fragments of DNA amplification.

Electrophoretic division of restrictive enzymes of DNA was carried out in $2 \%$ agarose gel and $9-12 \%$ of polyacrylamide gels in tris-borate electrophoresis buffer (TBE: $0.089 \mathrm{M}$ of boric acid, $0.002 \mathrm{M}$ EDTA pH 8.0). To apply the samples onto the gel, we used the buffer of the following composition: $0.25 \%$ bromphenol blue, 0.25 xylene cyanol, $30 \%$ glycerol. Agarose gel was electrophoresed in a horizontal chamber for 13 hours at the voltage of $2 \mathrm{~V} / \mathrm{cm}$. Electrophoresis of polyacrylamid gel was carried out in a vertical chamber for 10-12 hours at $80 \mathrm{~V}$. The gels were stained using ethidium bromide $(0.5 \mu \mathrm{g} / \mathrm{mL})$ for $10 \mathrm{~min}$, after which they were subjected to multiphase rinsing in distilled water. Fragments of DNA were visualized in a UV transilluminator at the wavelength of $280 \mathrm{~nm}$. To measure the length of fragments, we used molecular weight marker GeneRuler TM Ultra Low Range DNA Ladder manufactured by Fermentas, Latvia. The electrophoregrams obtained as a result were then subjected to analysis. Restrictive fragments were divided using electrophoresis in $9-12 \%$ polyacrylamide gel.

Amplification of exon 2 with the subsequent analysis of length of restriction fragments and comparisons of DNA patterns obtained using three restrictive endonucleases RsaI, XhoII and HaeIII allows the identification of 54 nomenclature alleles (Van Eijk et al., 1992; Gelhaus et al., 1995; Maillard et al., 1999). Apart from them, some studies found other alleles, undescribed using methods of PCR-RLFP, indicated as "without established nomenclature" (Oprzadek et al., 2012; Fernández et al., 2015). They are identified through the totality of the patterns of each of three restriction enzymes.

The allele $\left(\mathrm{P}_{\mathrm{a}}\right)$ and genotype $\left(\mathrm{G}_{\mathrm{a}}\right)$ frequencies, observed heterozygosity $\left(\mathrm{H}_{\mathrm{o}}\right)$ were determined by direct counting. Expected heterozygosity $\left(\mathrm{H}_{\mathrm{e}}\right)$ was determined through allele frequencies by the formula (Hedrick, 2010). Individual index of fixation was calculated through the observed and expected heterozygosity checked according to the test of $\chi^{2}$ (for single-locus system at $\mathrm{dF}=1$ and $\mathrm{N}$ of animals in calculation selection $\chi^{2}=$ $\mathrm{NF}_{\text {IS }}^{2}$ ).

While analyzing genetic variability, we determined the effective number of alleles (Hedrick, 2010) and index of major allele frequency (Pojskić, 2018):

$$
\begin{gathered}
A_{e}=1 /\left(1-H_{e}\right) \\
i M A F=\left(1 / N_{a}\right) / P_{m},
\end{gathered}
$$

where $\mathrm{P}_{\mathrm{m}}$ is frequency of major allele in the given locus.

Reliability of the results was evaluated according to Z-score (Z) indicator for the right-side hypothesis.

Assessment of allele variety was performed according to Shannon information index (Lebedeva et al., 2002), based on which we then calculated the evenness indicator or Pielou's evenness index (Pielou, 1966).

Frequencies of alleles and deviation from Hardy-Weinberg equilibrium (HWE) were calculated using PyPop-Win32-0.7.0 software (Lancaster et al., 2007). Test for normality of the distribution of frequencies of alleles was made using the Shapiro-Wilk statistic (SW) and KolmogorovSmirnov statistic with Lilliefors' significance (KS) in the standard software pack of IBM SPSS Statistics V24.0 (www.ibm.com/support/ knowledgecenter/ru/SSLVMB_24.0.0/spss/product_landing.html). 


\section{Results}

The results of the study revealed that the quantity and frequency of alleles in the surveyed selections significantly varied. In herd A, we found 12 variants, out of which only three alleles had frequencies exceeding $5 \%$. In herd B, we found 25 variants, that 4 alleles DRB $3.2 * 06, * 12, * 16, * 24 \mathrm{i}$ *jba had frequencies higher than $5 \%$ (Table 1). Typing of the sperm samples from the bulls had the following genotypes: Inzhyr (7927)*16/*16, Zenit $(2785) * 12 / * 12$, Hihant (5948) *16/*jba, Zapad (9705)*16/*16 and Barvinok $(8247) * 14 / * 16$

Table 1

The frequencies BoLA-DRB3.2 alleles of Ukrainian Gray breed

\begin{tabular}{|c|c|c|c|c|c|}
\hline \multirow{2}{*}{ Alleles } & \multicolumn{4}{|c|}{ frequencies, $\%$} & \multirow{2}{*}{$\chi^{2}$} \\
\hline & herd A & herd B & $P_{a}{ }^{1}$ & $P_{a}{ }^{I I}$ & \\
\hline *04 & 2.5 & - & 1.08 & 2.15 & 1.74 \\
\hline *06 & 15.0 & 2.1 & 7.53 & 14.00 & $4.38^{\mathrm{a}}$ \\
\hline *12 & 25.0 & 2.1 & 12.9 & 22.6 & $24.4^{\mathrm{b}}$ \\
\hline *14 & 1.3 & 4.2 & 3.23 & 6.45 & 0.03 \\
\hline *15 & 2.5 & 6.3 & 4.30 & 8.60 & 0.15 \\
\hline *16 & 43.8 & 42.7 & 44.1 & 67.7 & $460^{c}$ \\
\hline *20 & - & 3.1 & 1.61 & 3.23 & 1.07 \\
\hline *22 & - & 2.1 & 1.08 & 2.15 & 1.74 \\
\hline *23 & 2.5 & 2.1 & 2.15 & 4.30 & 0.57 \\
\hline *24 & - & 7.3 & 3.76 & 7.53 & 0.01 \\
\hline *53 & - & 2.1 & 1.08 & 2.15 & 1.74 \\
\hline *jba & - & 9.4 & 5.38 & 10.80 & 0.91 \\
\hline$* j b b$ & - & 3.1 & 1.61 & 2.15 & 1.07 \\
\hline Other & 7.4 & 13.4 & 10.2 & 12.9 & 30.9 \\
\hline In total & 100.0 & 100.0 & 100.0 & - & 532.9 \\
\hline
\end{tabular}

Note: the table presents alleles with frequency over $1 \% ; \mathrm{P}_{\mathrm{a}}{ }^{\mathrm{I}}$ calculation according to the total number of alleles (herd $\mathrm{A}+$ herd $\mathrm{B}+$ bulls); $\mathrm{P}_{\mathrm{a}}{ }^{\mathrm{II}}$ calculation according to the number of alleles in genotypes (herd $\mathrm{A}+$ herd $\mathrm{B}+$ bulls); Major alleles: ${ }^{\mathrm{a}}-\mathrm{P}<0.05$; ${ }^{\mathrm{b}}-\mathrm{P}<0.005 ;{ }^{\mathrm{c}}-\mathrm{P}<0.001$.

In total, comparison of restriction patterns of 93 samples of DNA allowed us to identify 28 alleles, including 23 variants that were nomenclature. The share of alleles "without established nomenclature" - jba, *jab, *jbb, *nad and *nda - accounted for $8.9 \%$. Interestingly, in the experimental population, there are alleles of jba and *ibb, that were previously found in Polish Holstein-Friesian cattle (Oprzadek et al., 2012), and also variants jba, *jab and *jbb, found in Mexican Creole cattle (Fernández et al., 2015). The breed is characterized by great unevenness of distribution of alleles. The total share of consolidating alleles of $(\mathrm{Pa} \geq 5 \%) \mathrm{BoLA}-$ DRB3. $2 * 06, * 12, * 16$ and $*$ jba equaled $69.9 \%$. Broadest distribution was seen in variant $* 16(44.1 \%)$.

In genetic studies, great importance belongs to significant alleles. They occur quite often or, on the contrary, rarely and have significant deviation from the normal distribution. Therefore, the traits related to them are usually associative. For such alleles, condition $\chi^{2} \geq 3.84(\mathrm{dF}=1)$ at $\mathrm{CI}=95 \%$ should be satisfied. In this case, the zero hypothesis about the normal (in our case even) distribution of the obtained variants in the study selection is discarded. Significant alleles are important for the population because the trait it is associated with makes them available to be used as DNA-markers. According to this condition, we distinguished three alleles: BoLA-DRB3.2*06, *12 and *16.

For the established frequency spectrum, the observed uneven distribution was reliable $\left(\Sigma \chi^{2}=532.9 ; \mathrm{P}>0.999\right.$ at $\left.\mathrm{dF}=27\right)$. This conclusion was confirmed according to tests of Kolmogorov-Smirnov and Shapiro-Wilk.

Table 2

Test for the normality of distribution of allele frequencies

\begin{tabular}{cccccc}
\hline \multicolumn{2}{c}{ Kolmogorov-Smimov Criteria * } & \multicolumn{4}{c}{ Shapiro-Wilk Criteria } \\
\hline KS & $\mathrm{dF}$ & $\mathrm{P}$ & $\mathrm{KS}$ & $\mathrm{dF}$ & $\mathrm{P}$ \\
\hline 0.241 & 27 & $<0.01$ & 0.832 & 27 & $<0.02$ \\
\hline
\end{tabular}

Note: *-with Lilliefor's correction.

Allele BoLA-DRB3.2*16 in its genome was found in each second animal out of three $(67.7 \%)$. In total, in the study selection, 40 genotypes were found. Taking into account significant dominance of variant $* 16$, as expected, 5 genotypes with its participation manifested: *16/*16 $(20.4 \%)$, *12/*16 (11.8\%), *06/*16 (7.53\%), *16/*24 (5.38\%) and *jba*16
(4.3\%), which overall accounted for $49.5 \%$ of the total number of tested animals. The determined excess of homozygotes was not statistically significant. Pearson's chi-squared test for single locus system at $\mathrm{dF}=1$ shows that obtained deviation from HWE was not significant $\left(\chi^{2}=0.159\right.$ $<\chi_{\text {min }}^{2}$ ). Therefore, the statement that inbreeding is possible in the population of Gray cattle is wrong, though denials of the selective effect on deviation from panmixia require additional experiments.

Results of the study on polymorphism of BoLA-DRB3 gene indicate that the Ukrainian Gray breed is characterized by a population with an uneven distribution of alleles, in which there is significant prevalence of variant BoLA-DRB3. $2 * 16$, with presence of prevailing genotypes with involvement of the same allele, insignificant deviation toward increase in homozygosity without distortion of the normal distribution according to the Hardy-Weinberg equilibrium.

Table 3

Parameters of polymorphism, genetic variability and biodiversity of Ukrainian Gray breed according to alleles of BoLA-DRB3.2

\begin{tabular}{lc}
\hline \multicolumn{1}{c}{ Indication } & Metric Value \\
\hline Number of animals & 93 \\
Alleles per locus & 28 \\
Effective number alleles & 4.42 \\
Number of homozygotes observed & 24.0 \\
\hline Number of homozygotes expected & 21.1 \\
Number of homozygotes & 69.0 \\
Number of heterozygotes & 71.9 \\
Heterozygosity observed & 0.742 \\
Heterozygosity expected & 0.774 \\
Individual Wright's F-statistics & 0.041 \\
Shannon's information index & 2.21 \\
Indicator of evenness & 0.663 \\
\hline
\end{tabular}

When comparing genetic diversity of various breeds, it is practical to use iMAF index. Graphic depiction of the results of calculation of index for arithmetic mean of consolidating alleles of BoLA-DRB3.2 for Ukrainian Gray and other breeds involved in the analysis (Table 4) is presented in Figure 3.

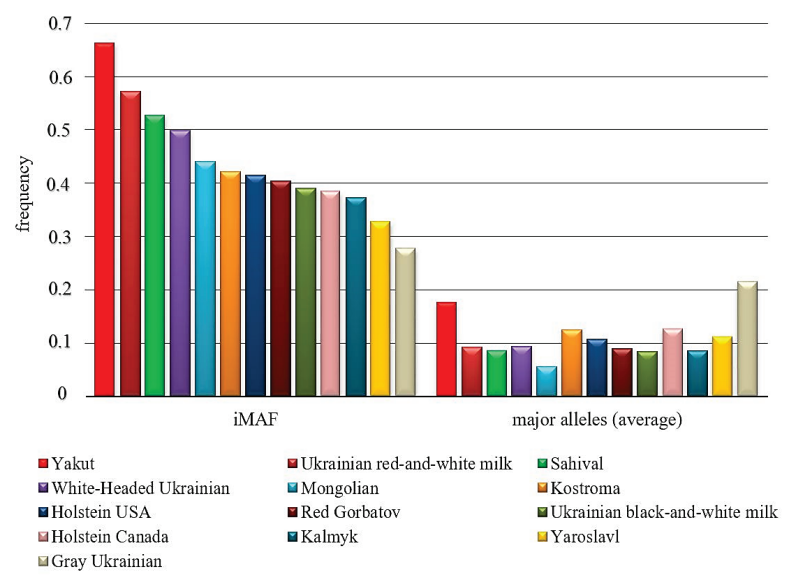

Fig. 3. Rating of consolidating alleles according to the $\mathrm{MAF}$ index

In Ukrainian Gray cattle, we found the lowest index iMAF $=0.277$ at highest mean frequency of major alleles $\mathrm{P}_{\mathrm{m}}=0.215$ and $\mathrm{Z}=1.88(\mathrm{P}<$ 0.03 ). Also, the breed was characterized by a low level of biodiversity according to Shannon's information index and Pielou's evenness index.

\section{Discussion}

Allele frequency is the indicator used for quantitative determination of genetic variability and the basis of all population genetic analyses (Gillespie, 2004). While identifying the status of the Ukrainian Gray breed according to the parameters of genetic variability and biodiversity, we compared genetic-population indicators of 12 breeds, for which we know the results of polymorphism of BoLA-DRB3 gene using PCR-RLFP method. According to well-known allele frequencies, we carried out the necessary calculations (Table 4). 


\section{Table 4}

The BoLA-DRB3.2 gene polymorphism and indicators of genetic variability and biodiversity calculated by allele frequencies for different cattle populations: expected $\left(\mathrm{H}_{\mathrm{e}}\right)$ and observed $\left(\mathrm{H}_{\mathrm{o}}\right)$ heterozygosity, inbreeding coefficient $\left(\mathrm{F}_{\mathrm{IS}}\right)$, effective allele number $\left(\mathrm{A}_{\mathrm{e}}\right)$,

Shannon's information index (I) and Pielou's evenness index $(\mathrm{J})$

\begin{tabular}{|c|c|c|c|c|c|c|c|c|c|c|}
\hline & \multirow{2}{*}{ Cattle population } & \multicolumn{2}{|c|}{ Alleles (list / total frequency) } & \multirow{2}{*}{$N_{a}$} & \multirow{2}{*}{$H_{o}$} & \multirow{2}{*}{$H_{e}$} & \multirow{2}{*}{$F_{I S}$} & \multirow{2}{*}{$A_{e}$} & \multirow{2}{*}{$I$} & \multirow{2}{*}{$J$} \\
\hline & & consolidating & significance & & & & & & & \\
\hline \multirow{4}{*}{ 莺 } & Yakut $^{a}$ & $* 18 ; * 29 ; * 45 ; * 50 ; * 54 / 88 ; 6$ & $\begin{array}{l}* 02^{m} ; * 07^{m} ; * 12^{m} ; * 17^{m} ; * 21^{m} ; * 23^{m} ; * 29 ; * 31^{m} ; \\
* 32^{m} ; 54 / 65.8\end{array}$ & 14 & 0.401 & 0.743 & 0.460 & 3.89 & 1.75 & 0.66 \\
\hline & Mongolian $^{a}$ & $* 07, * 18, * 20, * 26, * 28, * 29, * 46, * 49 / 51.2$ & $* 18, * 20, * 28 / 23.2$ & 35 & 0.775 & 0.954 & 0.188 & 21.7 & 3.24 & 0.91 \\
\hline & Kalmyk $^{a}$ & $* 12, * 15, * 24, * 28 / 34.1$ & $* 12, * 24, * 28 / 28.8$ & 36 & 0.818 & 0.948 & 0.137 & 19.2 & 3.29 & 0.92 \\
\hline & Yaroslavl $^{a}$ & $* 12, * 13, * 24, * 28 / 52.5$ & $* 12, * 13, * 24, * 28 / 47.5$ & 35 & 0.688 & 0.921 & 0.253 & 12.7 & 2.97 & 0.84 \\
\hline \multirow{4}{*}{ త్ర్ } & Sahiwal $^{b}$ & $* 02, * 06, * 08, * 10, * 15, * 37 / 51,5$ & $* 02,{ }^{*} 06, * 08, * 37 / 39.7$ & 24 & 0.857 & 0.944 & 0.092 & 17.9 & 2.25 & 0.71 \\
\hline & $\begin{array}{l}\text { White-Headed } \\
\text { Ukrainian }^{c}\end{array}$ & $* 03,{ }^{*} 12, * 14,{ }^{*} 16,{ }^{*} 22,{ }^{*} 23, * 24 / 65.3$ & $* 03, * 12, * 16, * 22, * 23, * 24 / 59.2$ & 23 & 0.957 & 0.928 & -0.031 & 13.9 & 2.61 & 0.83 \\
\hline & Kostroma $^{a}$ & $* 01, * 07, * 10, * 11, * 28, * 36 / 75.0$ & $* 07, * 10,{ }^{*} 11, * 28, * 36 / 69.3$ & 22 & 0.729 & 0.888 & 0.179 & 8.93 & 2.50 & 0.81 \\
\hline & Red Gorbatov $^{a}$ & $* 03, * 11, * 18, * 24 / 36.0$ & $* 03,{ }^{*} 11, * 18, * 24 / 36.0$ & 29 & 0.882 & 0.953 & 0.075 & 21.3 & 2.75 & 0.82 \\
\hline \multirow{4}{*}{ 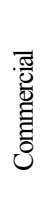 } & $\begin{array}{l}\text { Ukrainian black-and- } \\
\text { white milk }^{a}\end{array}$ & $* 03, * 08, * 10, * 22, * 24, * 28 / 50.3$ & $* 08, * 22, * 24, * 28 / 39.1$ & 32 & 0.922 & 0.938 & 0.017 & 16.1 & 3.06 & 0.88 \\
\hline & $\begin{array}{l}\text { Ukrainian red-and- } \\
\text { white milk }^{a}\end{array}$ & $* 01, * 03,{ }^{*} 07, * 11,{ }^{*} 16,{ }^{*} 22,{ }^{*} 24 / 59.4$ & $* 07,{ }^{*} 11,{ }^{*} 22, * 24 / 46.6$ & 22 & 0.864 & 0.921 & 0.062 & 12.7 & 2.77 & 0.89 \\
\hline & Holstein $\mathrm{USA}^{d}$ & $* 07, * 08, * 11, * 16, * 22 * 23, * 24 / 75.6$ & $* 08, * 11, * 16, * 22, * 23, * 24 / 70.3$ & 25 & - & 0.906 & - & 10.6 & 2.48 & 0.77 \\
\hline & Holstein Canada $^{e}$ & $* 03, * 08,{ }^{*} 11,{ }^{*} 16, * 22,{ }^{*} 23, * 24 / 88.7$ & $* 08, * 11, * 16, * 22, * 24 / 77.1$ & 26 & - & 0.865 & - & 7.41 & 2.29 & 0.7 \\
\hline
\end{tabular}

Note: ${ }^{\mathrm{a}}$ - Suprovych \& Suprovych (2020); ${ }^{\mathrm{b}}$ - Chakraborty et al. (2015); ${ }^{\mathrm{c}}$ - own research; ${ }^{\mathrm{d}}$ - Dietz et al. (1997); ${ }^{\mathrm{e}}$ - Sharif et al. (1998); $\mathrm{m}$ - minor allele frequency.

The uniqueness of the BoLA-DRB3 gene is that according to the level of variation the single-locus system exceeds multi-loci systems, providing possibilities of performing grounded analysis, having the data of distribution of alleles of only one gene. Frequency of emergence of various variants of BoLA-DRB3 locus varies greatly depending on breed, type, population of cattle. In our study, we determined that Ukrainian Gray cattle have 28 alleles of BoLA-DRB3.2 gene. Such a variation is characteristic of most studied breeds. According to the data of the review (Behl et al., 2012), among the breeds of species Bos taurus, 20 to 30 alleles are most often found. High allele diversity according to BoLA-DRB3 gene was determined for the Indian breed Malnad Gidda - 37 variants (Das et al., 2012), Kalmyk cattle - 36 variants, Russian Yaroslavl cattle (Sulimova, 2006) and Mongolian cattle (Ruzina et al., 2010) - 35 variants in each, (Ruzina et al., 2010) and Iranian zebu-like Sistani cattle - 32 variants (Mohammadi et al., 2009). The recent surveys of local and autochthonous breeds indicate that their allele polymorphism of the BoLA-DRB3 gene is broader than in the commercial and native ones. Therefore, in the Philippine native breed using PCR-SBT (Takeshima et al., 2014) and Mexican Creole breed using the PCR-RLFP method (Fernández et al., 2015) 71 alleles were found in each, and three indigenous breeds of Sudan were found to have 53 alleles (Salim et al., 2020), and 38 alleles in each were determined in Latin American Creole breeds (Giovambattista et al., 2013) and indigenous Korean breed Hanwoo (Lee et al., 2012). At the same time, up to a dozen and more new variants of alleles have been described, indicating that indigenous breeds remain highly diverse according to the BoLA-DRB3 gene. The exceptions are Yakutsk cattle, in which the low number of alleles may be a consequence of inbreeding depression caused by the low number of pathogens that affect them in the region where they live.

In multi-allele loci, we should pay attention to nomenclature of alleles. Among the obtained variants, the main attention should be drawn to consolidating and significant alleles and their total share. The set of consolidating alleles may be defined as the quantitative characteristic of the breed. Accumulation of 6-7 variants with overall share of over $75 \%$ indicates that most animals of the breed have these alleles in their own genotypes. Such a situation is developing as a result of long oriented selection, for example the situation with consolidating alleles in commercial breeds.

Distribution of alleles in autochthonous breeds has various patterns. Among them, there is a number of consolidating alleles: the lowest in Ukrainian Gray (4 variants) and Yakutsk (5 variants) cattle, and their total shares are large, $69.9 \%$ and $88.3 \%$ respectively. The Kalmyk and Yaroslavl breeds were observed to have only 4 alleles with frequencies over $5 \%$, though due to even distribution, their share in the allele fund was lower. Maximum number ( 8 of consolidating alleles) was seen in the Mongolian cattle.
Local breeds have been developed based on introduction to native cattle of genetic material from other breeds. For example, Red Gorbatov breed was created by cross-breeding native Prioksk cattle and bulls of the Tirol breed with subsequent pure breeding of hybrids, while the Kostroma breed was developed by cross-breeding native cattle with Allgau and Swiss cattle (Moiseeva et al., 2006). Ukrainian White-Headed cattle were created as a result of reproductive crossing of native cattle of the Polissya climatic zone and Groningen offspring of Dutch cattle (Shuplyk et al., 2013). Therefore, local breeds are characterized by unevenness of consolidating and significant alleles according to the nomenclature, amount and share in the allele fund.

Commercial breeds are local cattle that became broadly distributed, both geographically and quantitatively due to high productivity according to a certain trait. Quite often, they are used to improve economically useful traits of other breeds, leading to accumulation of alleles of the improving breed. There occurred a situation when Holstein cattle were massively used for increasing dairy productivity. A number of dairy breeds have been created using it, including Ukrainian black-and-white and red-andwhite dairy breeds, which are currently being modified by the principle of open populations with further use of genetic potential of Holstein cattle.

Research on Holstein herds in the USA (Dietz et al., 1997) and Canada (Sharif et al., 1998), revealed 7 consolidating alleles in each with total frequencies of $75.6 \%$ and $88.7 \%$, six of which $(* 08, * 11, * 16, * 22, * 23$ and $* 24$ ) had prevailing frequencies in both populations. They also had identically significant alleles $\left(* 08, * 11,{ }^{*} 16, * 22, * 23\right.$ and $\left.* 24\right)$, which in total amounted to $70.3 \%$ and $77.1 \%$. A similar set of consolidating alleles with permutation of the frequencies was found in Columbian Holstein (Gómez-Castro et al., 2006; Morales et al., 2020), Iranian (Nassiry et al., 2005), Argentinean (Juliarena et al., 2008), and also Polish Holstein (Oprzadek et al., 2018) and Holstein-Friesian (Oprzadek et al., 2012) cattle. In studies conducted in the Iranian population of Holstein bulls, seven most frequent alleles (BoLA-DRB3.2*08, *11,*16, *22, *24, *28 and *51) accounted for $80 \%$ of all found alleles (Parnian et al., 2006). Therefore, the abovementioned BoLA-DRB3.2 alleles were present in genotypes of Holsteinized cattle and were associated with traits considered introduced by the Holstein breed (Suprovych et al., 2017b). In domestic commercial breeds (Ukrainian black-and-white dairy, Ukrainian red-andwhite dairy), there were also found 6-7 alleles with frequency over $5 \%$, but their overall frequency was somewhat lower $-50.3 \%$ to $59.4 \%$.

Initial data will always concern polymorphism of loci, i.e., quantity and share of animals in the genotype of which the significance alleles were found. They need to be considered as qualitative genetic traits of a breed. Statistically significant deviation of allele frequencies from the normal 
distribution means that such a genetic unit is a distinctive trait of the breed. Two parameters of allele frequencies are special indicators: frequency of major allele frequency and minor allele frequency, when SNP and other biallelic loci are analyzed. Fluctuations of allele frequencies between and inside populations have evolutional value, when selective pressure aims at removal of deleterious alleles, favouring new genetic variants that provide the adaptive advantage. Selection may directly cause changes in the frequency of major and minor alleles. Significance of frequencies of such alleles in the assessment of genetic diversity has been the object of various studies (Kaur et al., 2014; Engelsma et al., 2013), because they are an indicator of genetic variability and polymorphism in the observed locus (Singh et al., 2013).

In Ukrainian Gray cattle, only 3 major alleles were found, with noteworthy prevalence of DRB3.2*16 variant with total frequency of $64.5 \%$. Among the analyzed populations, such a situation was characteristic only of Yakutsk cattle, where notable domination of two major PCR-RLFP alleles was seen: BoLA-DRB3.2*29 (42.9\%) and *54 (22.9\%). Only this breed was observed to have 8 minor alleles that had frequencies below $2 \%$. Two other native breeds, Mongolian and Kalmyk, also had three significant major alleles each, though with a much lower overall share, which may be explained by equal distribution of frequencies.

Other than allele frequencies in single loci, another important indicator that characterizes genetic variability of populations is heterozygosity. An animal that is heterozygous according to a certain gene has different alleles, i.e. bears double genetic information unlike the homozygous variant, thus illustrating variability. Accumulation of homozygous variants in a population reduces the amount of genetic information, impoverishing its biodiversity. In Ukrainian Gray cattle, we found one of the lowest heterozygosity parameters $\left(\mathrm{H}_{\mathrm{e}}=0.774\right)$ according to BoLA-DRB3 gene. The reason for this is significant prevalence of allele $* 16$ frequency. A similar situation was characteristic of Yakutsk cattle that had the lowest heterozygosity $\left(\mathrm{H}_{\mathrm{e}}=0.743\right)$ and two high-frequency alleles BoLADRB3. $2 * 29$ and $* 54$.

Significant accumulation of frequencies of several alleles is explained by the peculiarities of selection of various breeds. Artificial selection has determined the intense pressure on the species Bos taurus toward the development of genotypes associated with production of milk or meat, making the cow a convenient object for understanding the mechanisms of interaction between genotype and the environmental factors (Zerabruk et al., 2007). To a certain extent this also affects native breeds. Subject to the influence of such factors as migration of genes, selection, inbreeding, the discrete genetic load of populations is able to rapidly change frequency is found more often. Such phenomena are especially characteristic of lownumber populations, including autochthonous breeds. Pure breeding in native cattle leads to inbreeding.

The problem of heterozygosity is important regarding morbidity of cattle, because one of the hypotheses explaining the high level of polymorphism of MHC genes is heterosis. It was proposed due to the observations where particular allele products were observed to have various abilities to present alien protein T-cells. Selection to the advantage of heterozygotes leads to development of stable polymorphic balance, caused by antigen-binding functions of molecules of the complex. Heterozygous animals of populations in the zone of influence of numerous pathogens have the advantage of having the ability to bind more alien antigens (Hedrick et al., 1991). Therefore, equilibrium populations with minimum deviation from HWE characterized by excess of heterozygotes, while artificially developed breeds were seen to have varying levels of prevalence of homozygotes.

Deviation from Hardy-Weinberg equilibrium is determined according to Wright's fixation index. It assesses decrease in heterozygosity of animals due to random crossing within a population. Positive values of the index indicate possibility of closely related crossing, and its value shows that in the next generations, using the same levels of relative mating, homozygosity on average will increase by magnitude FIS. Inbreeding is considered tight (blood-mixing) at coefficient of $25 \%$ and higher, close at $12.5-25.0 \%$, moderate at $1.55-12.50 \%$, and remote at $0.20-1.55 \%$ (Sharafutdinov et al., 2019). Mongolian and Kalmyk cattle kept in the conditions of free grazing and crossing were observed to have prevalence of homozygotes within the moderate thresholds. The Yakutsk breed had an excessive surplus of homozygotes $\left(\mathrm{F}_{\mathrm{IS}}=0.46, \mathrm{P}<0.001\right)$, which may have been a consequence of the fact that low-number populations that live in the conditions of low amount of disease pathogens tend to experience inbreeding depression. Inbreeding leads to decrease in biodiversity, contributes to spread of genetic diseases, causes lower fertility and weakens resistance to diseases. Moreover, "genetic purity" in diploid species provides no clear definition in molecular aspect. Controlled cross-breeding has been being practiced for centuries and is not always undesired. Practically, it has never reduced the role of a native breed in conditions of conservation of its type peculiarities.

The Ukrainian Gray breed is beneficially different from the other native breeds. Thanks to scientifically-based selective work, purpose-oriented stabilizing selection has been conducted, taking into account determination of traits and consolidation of peculiarities of the Gray cattle. A study was conducted on microevolutionary changes in ratio of its geno- and phenotypes using express prediction of optimum additional selection and selection of geno- and phenotypes over the last 64 years, at the same time predicting productivity of parents and future descendants in a closed population (Kozyr, 2016). Therefore, deviation of distribution of heterozygotes from HWE in Gray cattle accounted only for $4.1 \%(\mathrm{P}<0.001)$.

Variability of genetic variance is easier to measure in Ae units. The number of effective alleles is the quantity of alleles with the same frequency (in the conditions of unequal heterozygosity), necessary to achieve certain level of diversity, thus allowing one to compare the populations where quantity and distribution of allele variants are strikingly contrasting. In the Ukrainian Gray breed, this parameter is quite low (Ae $=$ 4.42). Such a situation is characteristic of populations where one allele (the only actual factor favourable for the effective number of alleles) dominates, while all other variants occur rarely. A similar situation is observed in Yakutsk cattle. The parameter of the number of effective alleles is most often used to compare biodiversity of various populations, therefore obtained Ae values should not be considered a characteristic trait of genetic variability of breeds. It is confirmed by the fact that the numbers of effective alleles in Kalmyk and Mongolian cattle were 21.7 and 19.2, some of the highest among other breeds. Low Ae parameters in Holstein and Kostroma breeds at similar values of $\mathrm{Na}$ are explained by broad variation in allele frequencies. Variants with frequencies remote from paired "average" ones contribute very little to the effective number of alleles.

The parameter of $\mathrm{MAF}$ indicates to what extent the highest frequency exceeds the expected one, assuming the frequencies of all found alleles in this locus are equal. Indices with values close to 1 have positive prediction of the distribution of allele frequencies in this locus in observed populations. A high iMAF index indicates better genetic potential of this population from the perspective of diversity. The range of the index is within 0 to 1 , where 0 means absence of polymorphism in a locus, and 1 indicates absence of a major allele and equal frequency of all detected variants in a locus.

Ukrainian Gray cattle (Fig. 3) were found to have the lowest index $\mathrm{iMAF}=0.277$ among all the analyzed breeds. The maximum calculated value of $\mathrm{iMAF}=0.664$ was in the Yakutsk breed at $\mathrm{P}_{\mathrm{m}}=0.177$, though with quite low level of significance $(\mathrm{Z}=0.885$ at $\mathrm{P}<0.188)$. This indicates that cumulative alleles tend to increase their presence in a population, but the chance of losing minor alleles is low, and the parameter itself is sensitive to quantity of detected alleles. Among other breeds, the allowable level of likelihood, other than Ukrainian Gray breed, was observed in four other breeds: Yaroslavl $-\mathrm{iMAF}=0.328, \mathrm{P}_{\mathrm{m}}=0.112, \mathrm{Z}=2.35(\mathrm{P}<0.01)$; Kalmyk $-\mathrm{iMAF}=0.373, \mathrm{P}_{\mathrm{m}}=0.085, \mathrm{Z}=2.21(\mathrm{P}<0.014)$; Red Gorbatov $-\mathrm{iMAF}=0.404, \mathrm{P}_{\mathrm{m}}=0.09, \mathrm{Z}=2.16(\mathrm{P}<0.016)$ and Ukrainian blackand-white dairy breed $-\mathrm{iMAF}=0.391, \mathrm{P}_{\mathrm{m}}=0.084, \mathrm{Z}=1.7(\mathrm{P}<0.045)$. By selecting frequencies of major alleles according to iMAF, it is possible to predict their distribution so as to determine possible selective actions in order to preserve biodiversity based on molecular-genetic markers, because DNA-technologies are quite efficient in analyzing the gene fund structures of herds of indigenous breeds.

According to the law of required Wiener-Shannon-Ashby diversity for stable existence of a biological system, it must necessarily be diverse internally to be able to block any external and internal disturbances. Its value may be assessed using the Shannon index based on the formula of entropy, reflecting the extent of non-subordination of the distribution of 
the elements of the system. The highest value of the index corresponds to greatest degree of "chaoticity" of allele distribution. The lower is the value of the index, the higher is evenness in distribution of allele frequencies. The index is sensitive to changes in frequencies of major components of the system, making it a convenient tool for analysis of biodiversity of multi-allele exon 2 of BoLA-DRB3 gene. For Ukrainian Gray cattle, the parameter of the Shannon index was low, equaling $\mathrm{I}=2.21$. Higher values were determined for breeds that had the highest number of alleles. Respectively, it was $\mathrm{I}=3.29$ and $\mathrm{N}_{\mathrm{a}}=35$ in Kalmyk cattle, $\mathrm{I}=3.24$ and $\mathrm{N}_{\mathrm{a}}=34$ in Mongolian cattle, $\mathrm{I}=2.97$ and $\mathrm{N}_{\mathrm{a}}=35$ in Yaroslavl cattle and $\mathrm{I}=3.06$ and $\mathrm{N}_{\mathrm{a}}=32$ in Ukrainian black-and-white cattle.

To level out the deviation of the parameters obtained above due to prevalence of a large number of alleles in some breeds and to elaborate the assessments of uneven distribution of allele frequencies, we calculated the Pielou evenness index. It is more balanced regarding the dispersion of frequency fluctuations of the system, practically does not depend on the number of the elements that form it and therefore most accurately depicts the diversity of the system. According to the Pielou index, Ukrainian Gray cattle, along with Yakutsk cattle, have the lowest parameter, equaling $\mathrm{J}=$ 0.66. Also, an insignificant level of allele biodiversity of BoLA-DRB3.2 gene was seen in Holstein and Sahiwal breeds. The largest parameters of biodiversity, despite the evenness, have remained in the Kalmyk $(J=0.92)$ and Mongolian $(\mathrm{J}=0.91)$ native breeds.

Abnormal distribution of BoLA-DRB3.2*16 allele in the Ukrainian Gray breed has its own disadvantages and advantages. Its significant dominance causes low level of genetic variability and biodiversity, as confirmed by the parameters of heterozygosity, effective number of its alleles, Shannon and Pielou indices.

On the other hand, share of allele is specific weight of all alleles of this gene in a population. While determining the statistically significant relationship between it and a certain phenotypic trait (disease, economically useful trait, etc.), it may be used as a DNA marker. Usually, an allele that is manifested to the highest degree is first of all competing for such a role, whereas the animal in the genotype of which it is present, has determining status in selective breeding programs.

There are numerous studies where associations of the BoLADRB3.2*16 allele with various phenotypic traits of cattle were determined. For example, surveys by Iowa State University of blood samples from 137 pregnant herd cows revealed the relationship between DRB3.2*16 allele and higher value SCC (somatic cell count) (Kelm et al., 1997). Studies of 100 Holstein cows on farms (Giza, Egypt), that were regularly diagnosed with clinical and subclinical forms of mastitis, revealed 3 alleles of DRB3.2*11, *16 and *24, which had a genetically-caused relationship with mastitis, and at the same time, allele *11 was related to susceptibility, while allele $* 16$ was associated with resistance to the disease. The obtained results have high statistical significance and indicate that the determined alleles may be recommended as markers the application of which range from selecting animals at a young age to actual use of them in a productive herd (Ibrahim et al., 2012). Research on a population of 350 Iranian Holstein dairy cattle revealed that close relationship with the diseases of the udder was manifested by alleles $* 08, * 23$ and $* 24$, and resistance was displayed by $* 03, * 11$ and $* 16$ (Nikbakht et al., 2012). Research on blood samples from 45 cows of the Sarabi (Iranian native) breed revealed association of DRB3. $2 * 16$ allele with resistance to mastitis (Firouzamandi et al., 2010). In Holstein cows (Canada) this allele was associated with low risk $(\mathrm{P}<0.05)$ of the development of cystic ovarian disease and lowest values of $(\mathrm{P}<0.05) \mathrm{SCC}$ in milk (Sharif et al., 1998). A similar situation was found in the study of associations of BoLA-DRB3 genotype with the number of somatic cells in milk from 808 Polish Holstein cows, where the decrease of SCC was determined for cows that had allele *16 in genotype $(\mathrm{P}<0.01)$ (Oprzadek et al., 2018). Gene typing using the PCR-RLFP method on 548 Canadian and American Holstein bulls revealed that the BoLA-DRB3.2*16 allele had a favourable effect on durability of productive herd life, as compared with allele $* 23$, and genotype BoLA-DRB3.2*16/*23 had a favourable effect on daughter fertility (Sharma et al., 2011). Also, there are other significant associative relationships between prevalent alleles BoLA-DRB3.2*06 and *12 of Gray Ukrainian cattle and useful traits.

\section{Conclusions}

Genetic studies of MHC of Ukrainian Gray cattle using the PCRRLFP method revealed peculiarities of polymorphism of alleles of exon 2 of the BoLA-DRB3 gene. The breed has a specific distribution of BoLADRB3. $2 * 16$ allele variants, and is characterized by the extremely high weight of the allele *16 and consolidation of major alleles. Domination of $* 16$ allele was also manifested through its presence in $2 / 3$ of surveyed animals. The population of Ukrainian Gray cattle is low and territorially they are kept only on two farms. These factors cause a low level of genetic variability and biodiversity. Despite this and significant prevalence of one allele, this breed has no inbreeding motifs characteristic of such populations.

Surveys of polymorphism of BoLA-DRB3 gene confirm the thesis that Ukrainian Gray cattle, as with any other autochthonous breed, is characterized by a specific gene fund and unique genetic parameters, which the modern commercial breeds have lost. Therefore, study of polymorphism of alleles of BoLA-DRB3.2 gene in this breed may be useful for genetic-populational programs with the purpose of improving the genetic potential of breeds of cattle. Such studies should be continued in order to determine association between alleles of BoLA-DRB3.2 gene of Ukrainian Gray cattle and useful traits and various diseases of cattle.

\section{References}

Al-Samarai, R. F., \& Al-Kazaz, A. A. (2015). Molecular markers: An introduction and applications. European Journal of Molecular Biotechnology, 9(3), 119-130.

Behl, J. D., Verma, N. K., Behl, R., \& Sodhi, M. (2009). Genetic variation of the major histocompatibility complex DRB3.2 locus in the native Bos indicus cattle breeds. Asian Australasian Journal of Animal Sciences, 22(11), 1487-1494.

Behl, J. D., Verma, N. K., Behl, R., Mukesh, M., \& Ahlawat, S. P. S. (2007). Characterization of genetic polymorphism of the bovine lymphocyte antigen drb3.2 locus in Kankrej Cattle (Bos indicus). Journal of Dairy Science, 90(6), 2997 3001 .

Behl, J. D., Verma, N. K., Tyagi, N., Mishra, P., Behl, R., \& Joshi, B. K. (2012). The major histocompatibility complex in Bovines: A review. ISRN Veterinary Science, 2012, 872710.

Bodnaruk, V., Shchebatyj, Z., Muzyka, L., Zhmur, A., \& Orikhivskyj, T. (2017). Genofond of some breed of cattle. Scientific Messenger LNUVMBT named after S. Z. Gzhytskyj, 19(74), 131-134.

Brown, J. H., Jardetzky, T. S., Gorga, J. C., Stern, L. J., Urban, R. G., Strominger, J. L., \& Wiley, D. C. (1993). Three-dimensional structure of the human class II histocompatibility antigen HLA-DR1. Nature, 364, 33-39.

Chakraborty, D., Singh, A., Tantia, M., Verma, A., \& Chakravarty, A. (2015). Genetic polymorphism of BoLA-DRB3.2 locus in Sahiwal cattle. Animal Science Reporter, 9(1), 33-40.

Das, D. N., Sri Hari, V. G., Hatkar, D. N., Rengarajan, K., Saravanan, R., Suryanarayana, V. V. S., \& Murthy, L. K. (2012). Genetic diversity and population genetic analysis of bovine MHC class II DRB3.2 locus in three Bos indicus cattle breeds of Southern India. International Journal of Immunogenetics, 39(6), 508-519.

Dietz, A. B., Cohen, N. D., Timms, L., \& Kehrli, M. E. (1997). Bovine lymphocyte antigen class II alleles as risk factors for high somatic cell counts in milk of lactating dairy cows. Joumal of Dairy Science, 80(2), 406-412.

Engelsma, K. A., Veerkamp, R. F., Calus, M. P. L., \& Windig, J. J. (2013). Consequences for diversity when animals are prioritized for conservation of the whole genome or of one specific allele. Journal of Animal Breeding and Genetics, 131(1), 1-10.

Fernández, I. G., Leyva-Baca, I., Rodríguez-Almeida, F., Ulloa-Arvizu, R., RíosRamírez, J. G., Gayosso-Vázquez, A., \& Alonso-Morales, R. A. (2015). Creole cattle from northwestern Mexico has high genetic diversity in the locus DRB3.2. Animal Genetic Resources, 2015, 1-8.

Firouzamandi, M., Shoja, J., Bazegari, A., \& Roshani, E. (2010). Study on the association of BoLA-DRB3.2 alleles with clinical mastitis in Iranian Holstein and Sarabi (Iranian native) cattle. African Journal of Biotechnology, 9(15), 2224-2228.

Fox, C. W., \& Reed, D. H. (2011). Inbreeding depression increases with environmental stress: An experimental study and meta-analysis. Evolution, 65(1), 246-258.

Fries, R., Aggen, A., \& Womack, J. E. (1993). The bovine genome map. Mammalian Genome, 4, 405-428.

Gelhaus, A., Schnittger, L., Mehlitz, D., Horstmann, R. D., \& Meyer, C. G. (1995). Sequence and PCR-RFLP analysis of 14 novel BoLADRB3 alleles. Animal Genetics, 26(3), 147-153. 
Gillespie, J. H. (2004). Population genetics: A concise guide. 2nd ed. The Johns Hopkins University Press, Baltimore.

Giovambattista, G., Moe, K. K., Polat, M., Borjigin, L., Hein, S. T., Moe, H. H., Takeshima, S. N., \& Aida, Y. (2020). Characterization of bovine MHC DRB3 diversity in global cattle breeds, with a focus on cattle in Myanmar. BMC Genetics, 12,95 .

Giovambattista, G., Takeshima, S. N., Ripoli, M. V., Matsumoto, Y., Franco, L. A. Saito, H., Onuma, M., \& Aida, Y. (2013). Characterization of bovine MHC DRB3 diversity in Latin American creole cattle breeds. Gene, 519(1), 150-158.

Gladyr, E. A., Zinovieva, N. A., Bykova, A. S., Vinogradova, I. V., \& Ernst, L. K. (2012). Molochnaja produktivnost' korov v zavisimosti ot inficirovannosti virusom lejkoza i genotipa po BOLA-DRB3 [Milk productivity of cows in dependence of the infection by BVL and genotype on BOLA-DRB3]. Achievements of Science and Technology of the Agro-Industrial Complex, 8, 46- 48 (in Russian).

Glass, E. J., Oliver, R. A., \& Russell, G. C. (2000). Duplicated DQ-haplotype increase the complexity of restriction element uses in cattle. The Journal of Immunology, 165, 134-138

Gómez-Castro, S., Trujillo-Bravo, E., Carlos-Vicente, D., \& Agron, I. (2006). Polimorfismos de BoLA-DRB3 en el bovino sintético colombiano Lucerna y asociación con conteo de células somáticas y mastitis [BoLA-DRB3 Polymorphism in Colombian synthetic cattle Lucerna and association with somatic cell counts and mastitis]. Revista Colombiana de Ciencias Pecuarias, 19(3), 270 279 (in Spanish)

Guzjejev, J. V. (2014). Genezis genofondu aborygennykh porid velykoji rogatoji hudoby Ukrajiny [Genesis of the gene pool of native cattle breeds of Ukraine] Scientific Messenger LNUVMBT named after S. Z. Gzhytskyj, 16(3), 72-80 (in Ukrainian).

Hedrick, P. (2010). Genetic of populations. 4th ed. Mass Jones and Bartlett Publishers, Sudbury.

Hedrick, P. W., Whittam, T. S., \& Parham, P. (1991). Heterozygosity at individual amino acid sites: Extremely high levels for HLA-A antigens are associated with protection from severe malaria. Proceedings of the National Academia of Sciences USA, 88(13), 5897-5901.

Hughes, A. L., \& Nei, M. (1989). Nucleotide substitution at major histocompatibility complex class II loci: Evidence for overdominant selection. Proceedings of the National Academy of Sciences of the USA, 86, 958-962.

Huzeyev, Y., Melnyk, O., Spyrydonov, V., \& Melnychuk, S. (2016). Comparative analysis of genetic structure of a micropopulation of Gray Ukrainian breed cattle by DNA markers. The Animal Biology, 18(1), 22-26.

Ibrahim, E. A., Allam, N. A. T., Kotb, E. E. Z., El-Rafey, G. A., El-Deen, M. M. A \& Fadlallah, M. G. (2012). Sequence-based typing-study on the relationship between subclinical mastitis and BoLA-DRB3.2* allelic polymorphism in Egyptian cows. Global Veterinaria, 9(1), 8-22.

Juliarena, M. A., Poli, M., Sala, L., Ceriani, C., Gutierrez, S., Dolcini, G., Rodríguez, E. M., Mariño, B., Rodríguez-Dubra, C., \& Esteban, E. N. (2008). Association of BLV infection profiles with alleles of the BoLADRB3.2 gene. Animal Genetics, 39(4), 432-438

Kaur, S., Cogan, N. O. I., Forster, J. W., \& Paull, J. G. (2014). Assessment of genetic diversity in Faba bean based on single nucleotide polymorphism. Diversity, 6(1), 88-101.

Kelm, S. C., Detilleux, J. C., Freeman, A. E., Kehrli, M. E., Dietz, A. B., Fox, L. K., Butler, J. E., Kasckovics, I., \& Kelley, D. H. (1997). Genetic association between parameters of inmate immunity and measures of mastitis in periparturient Holstein cattle. Journal of Dairy Science, 80, 1767-1775.

Kozyr, V. S. (2006). Zberezhennia genofondu siroji ukrajins'koji porody [Preservation of the gene pool of the Gray Ukrainian breed]. Livestock in Ukraine, 10 11, 25-28 (in Ukrainian).

Kozyr, V. S. (2016). Sira ukrajins'ka poroda: Nacional'ne nadbannia na mezhi znyknennia [Gray Ukrainian breed: National heritage on the verge of extinction]. Agribusiness Today, 22(317), 38-42 (in Ukrainian).

Lancaster, A. K., Single, R. M., Solberg, O. D., Nelson, M. P., \& Thomson, G. (2007). PyPop update - a software pipeline for large-scale multilocus population genomics. Tissue Antigens, 69, 192-197.

Lazebnaya, I. V., Perchun, A. V., \& Lazebny, O. E. (2020). Intrabreed and interbreed variation of the BOLA-DRB3.2 gene in the Kostroma and Yaroslavl indigenous Russian cattle breeds. Immunogenetics, 72, 355-366.

Lebedeva, N. V., \& Krivoluckij, D. A. (2002). Biologicheskoe raznoobrazie i metody ego ocenki [Biodiversity and methods of its assessment]. In: Geografija $\mathrm{i}$ monitoring bioraznoobrazija [Geography and monitoring of biodiversity]. Lomonosov Moscow State University, Moscow (in Russian).

Lee, B. Y., Hur, T. Y., Jung, Y. H., \& Kim, H. (2012). Identification of BoLADRB3.2 alleles in Korean native cattle (Hanwoo) and Holstein populations using a next generation sequencer. Animal Genetics, 43(4), 438-441.

Maillard, J. C., Renard, C., Chardon, P., Chantal, I., \& Bensaid, A. (1999). Characterization of 18 new BoLA-DRB3 alleles. Animal Genetics, 30, 200-203.

Miyasaka, T., Takeshima, S. N., Matsumoto, Y., Kobayashi, N., Matsuhashi, T., Miyazaki, Y., Tanabe, Y., Ishibashi, K., Sentsui, H., \& Aida, Y. (2011). The di- versity of bovine MHC class II DRB3 and DQA1 alleles in different herds of Japanese black and Holstein cattle in Japan. Gene, 472, 42-49.

Miyasaka, T., Takeshima, S. N., Sentsu, H., \& Aida, Y. (2012). Identification and diversity of bovine major histocompatibility complex class II haplotypes in Japanese black and Holstein cattle in Japan. Journal of Dairy Science, 95(1), 420-431.

Mohammadi, A., Nassiry, M. R., Mosafer, J., Mohammadabadi, M. R., \& Sulimova, G. E. (2009). Distribution of BoLA-DRB3 allelic frequencies and identification of a new allele in the Iranian cattle breed Sistani (Bos indicus). Russian Journal of Genetics, 45(2), 224-229.

Moiseeva, I. G., Ukhanov, S. V., Stolpovskiy, Y. A., Sulimova, G. E., \& Kashtanov, S. N. (2006). Genofondy selskokhozyaystvennykh zhivotnykh [Gene pool of farm animals]. Nauka, Moscow (in Russian).

Morales, J. P., López-Herrera, A., \& Zuluaga, J. E. (2020). Association of BoLA DRB3 gene polymorphisms with BoHV-1 infection and zootechnical traits. Open Veterinary Joumal, 10(3), 331-339.

Mota, A. F., Martinez, M. L., \& Coutinho, L. L. (2004). Genotyping BoLA-DRB3 alleles in Brazilian cattle (Bos indicus) by temperature gradient gel electrophoresis (TGGE) and direct sequencing. European Journal of Immunogenetics, 31(3), 31-35

Nassiry, M. R., Shahroodi, F. E., Mosafer, J., Mohammadi, A., Manshad, E., Ghazanfari, S., Mohammad Abadi, M. R., \& Sulimova, G. E. (2005). Analysis and frequency of bovine lymphocyte antigen (BoLA-DRB3) alleles in Iranian Holstein cattle. Genetika, 41(6), 817-822

Nikbakht, G., Ranjbar, M. M., Ghasemi, F., \& Asadian, F. (2012). Allelic polymorphism in exon 2 of the BoLA-DRB3 gene in Iranian Holstein cows. Animal Production Research, 1(2), 33-41.

Oprzadek, J., Brzozowska, A. M., Urtnowski, P., Rutkowska, K., \& Lukaszewicz, M. (2018). Association of BoLA-DRB3 genotype with somatic cell count in milk of Polish Holstein cattle. Brazilian Journal of Animal Science, 47, e20150290.

Oprzadek, J., Urtnowski, P., Sender, G., Pawlik, A., \& Lukaszewicz, M. (2012). Frequency of BoLA-DRB3 alleles in Polish Holstein-Friesian cattle. Animal Science Papers and Reports, 30(2), 91-101.

Park, C., Russ, I., Da, Y., \& Lewin, H. A. (1995). Genetic mapping of F13A to BTA23 by spermtyping: Difference in recombination rate between bulls in the DYA-PRL interval. Genomics, 27(1), 113-118.

Parnian, M., Ghorashi, S. A., Selehi, A., Pashmi, M., \& Mollasalehi, M. R. (2006). Polymorphism of bovine lymphocyte antigen DRB3.2 in Holstein bulls of Iran using PCR-RFLP. Iranian Journal of Biotechnology, 4, 197-200.

Pielou, E. C. (1966). Shannon's formula as a measure of species difersity: Its use and misure. The American Naturalist, 100(914), 463-465.

Pojskić, N. (2018). iMAF - index of major allele frequency. Genetics and Applications, 2(2), 78-81.

Ruzina, M. N., Shtyfurko, T. A., Mohammad Abadi, M. R., Gendzhieva, O. B., Cedev, C., \& Sulimova, G. E. (2010). Polimorfizm gena BoLA-DRB3 u krupnogo rogatogo skota mongol'skoj, kalmyckoj i jakutskoj porod [Polymorphism of the BoLA-DRB3 gene in the Mongolian, Kalmyk, and Yakut cattle breeds]. Russian Journal of Genetics, 46(4), 517-525 (in Russian).

Scherf, B. D. (2000). World watch list for domestic animal diversity. 3rd ed. Food and Agriculture Organization of the United Nations, Rome.

Sharafutdinov, G. S., Sibagatullin, F. S., Balakirev, N. A., Shajdullin, R. R., Shuvarikov, A. S., Askarov, R. S., \& Sharafutdinova, J. A. (2019). Tehnologija proizvodstva produkcii zhivotnovodstva [Standardization, technology of processing and storage of livestock products]. Lan, Kazan (in Russian)

Sharif, S., Mallard, B. A., Wilkie, B. N., Sargeant, J. M., Scott, H. M., Dekkers, J. C. \& Leslie, K. E. (1998). Associations of the bovine major histocompatibility complex DRB3 (BoLA-DRB3) alleles with occurrence of disease and milk somatic cell score in Canadian dairy cattle. Animal Genetics, 29, 185-193.

Sharif, S., Mallard, B. A., Wilkie, B. N., Sargeant, J. M., Scott, H. M., Dekkers, J. C. \& Leslie, K. E. (1999). Associations of the bovine major histocompatibility complex DRB3 (BoLA-DRB3) with production traits in Canadian dairy cattle. Animal Genetics, 30(2), 157-160.

Sharma, B. S. Verschoor, C. P. \& Karrow, N. A (2011). Short communication: Associations of BoLA alleles DRB3.2*16 and DRB3.2*23 with health-related traits in Holstein bulls. Canadian Journal of Animal Science, 91, 597-600.

Shuplyk, V. V., Savchuk, O. V., \& Huzyev, I. V. (2013). Henofond porid sil's'kohospodars'kykh tvaryn Ukrajiny [Stock gene pool of agricultural animals of Ukraine] Private Enterprise Zvolieyko D. G., Kamenets-Podilskiy (in Ukrainian).

Singh, N., Choudhury, D. R., Singh, A. K., Kumar, S., Srinivasan, K., Tyagi, R. K., Singh, N. K., \& Singh, R. (2013). Comparison of SSR and SNP markers in estimation of genetic diversity and population structure of Indian rice varieties. PLoS One, 8(12), e84136.

Singh, U., Deb, R., Alyethodi, R., Alex, R., Kumar, S., Chakraborty, S., Dhama, K. \& Sharma, A. (2014). Molecular markers and their applications in cattle genetic research: A review. Biomarkers and Genomic Medicine, 6, 49-58.

Sommer, S. (2005). The importance of immune gene variability (MHC) in evolutionary ecology and conservation. Frontiers in Zoology, 2(16), 1-18 
Starkenburg, R. J., Hansen, L. B., Kehrli, M. E., \& Chester-Jones, H. J. (1997). Frequencies and effects of alternative DRB3.2 alleles of bovine lymphocyte antigen for Holsteins in milk selection and control lines. Dairy Science, 80(12), 3411-3419.

Stolpovskij, J. A., Glazko, V. I., Oblap, R. V., \& Kushnir, V. A. (1998). Fenotypycheskaja y genetycheskaja struktura seroj ukraynskoj porody krupnogo rogatogo skota [The phenotypic and genetic structure of the Ukrainian Gray cattle breed]. Cytology and Genetics, 32(5), 54-66 (in Russian).

Sulimova, G. E. (2004). DNK-markery v geneticheskih issledovanijah: Tipy markerov, ih svojstva i oblasti primenenija [DNA markers in genetic research: Marker types, their properties and applications]. The Success of Modern Biology, 124(3), 260-271 (in Russian).

Sulimova, G. E. (2006). DNK-markery v izuchenii genofonda porod krupnogo rogatogo skota [DNA markers in the study of gene pool of cattle breeds]. Genofondy sel'skohozjajstvennyh zhivotnyh: Geneticheskie resursy zhivotnovodstva Rossii. Nauka, Moscow. Pp. 138-166 (in Russian).

Suprovich, T., \& Mokhnachova, N. (2017). Gene polymorphism of economicallyuseful traits in Ukrainian Gray cattle breed. The Animal Biology, 19(1), 111-118.

Suprovych, T. M., \& Suprovych, M. P. (2020). Polimorfizm gena BoLA-DRB3 jak marker chutlyvosti do zahvorjuvan' velykoji rogatoji hudoby [BoLA-DRB3 gene polymorphism as a marker of susceptibility to cattle diseases]. State Agrarian and Engineering University in Podilia, Kamianets-Podilskyi (in Ukrainian).

Suprovych, T. M., Suprovych, M. P., \& Kolinchuk, R. V. (2017b). Consequences of "holsteinization" of Ukrainian black-pied dairy breed by gene BoLA-DRB3.2. Animal Breeding and Genetics, 54, 146-156 (in Ukrainian).

Sydorenko, O. V., \& Gyzieev, Y. V. (2019). Assessment of genetic variability of dam Ukrainian Gray breed cattle by blood group systems and microsatellite loci. Animal Science and Food Technology, 10(3), 56-62.

Takeshima, S. N., Corbi-Botto, C., Giovambattista, G., \& Aida, Y. (2018). Genetic diversity of BoLA-DRB3 in South American Zebu cattle populations. BMC Genetics, 19, 33 .
Takeshima, S. N., Giovambattista, G., Okimoto, N., Matsumoto, Y., Rogberg-Muñoz, A., Acosta, T. J., Onuma, M., \& Aida, Y. (2015a). Characterization of bovine MHC class II DRB3 diversity in South American Holstein cattle populations. Tissue Antigens, 86(6), 419-430.

Takeshima, S. N., Miyasaka, T., Matsumoto, Y., Xue, G., Diaz, V., Rogberg-Munoz, A., Giovambattista, G., Ortiz, M., Oltra, J., Kanemaki, M., Onuma, M., \& Aida, Y. (2015b). Assessment of biodiversity in Chilean cattle using the distribution of major histocompatibility complex class II BoLA-DRB3 allele. Tissue Antigens, 85(1), 35- 44.

Takeshima, S. N., Miyasaka, T., Polata, M., Kikuya, M., Matsumoto, Y., Mingala, C. N., Villanueva, M. A., Salces, A. J., Onuma, M., \& Aida, Y. (2014). The great diversity of major histocompatibility complex class II genes in Philippine native cattle. Meta Gene, 2, 176-190.

Takeshima, S., Saitou, N., Morita, M., Inoko, H., \& Aida, Y. (2003). The diversity of bovine MHC class II DRB3 genes in Japanese black, Japanese shorthom, Jersey and Holstein cattle in Japan. Gene, 316, 111-118.

Thiel, T., Kota, R., Grosse, I., Stein, N., \& Graner, A. (2004). SNP2CAPS: a SNP and INDEL analysis tool for CAPS marker development. Nucleic Acids Research, 32(1), e5.

Van Eijk, M. J. T., Stewart-Haynes, J. A., \& Lewin, H. A. (1992). Extensive polymorphism of the BoLA-DRB3 gene distinguished by PCR-RFLP. Animal Genetics, 23(6), 483-496.

Yuhki, N., \& O'Brien, S. J. (1990). DNA variation of the mammalian major histocompatibility complex reflects genomic diversity and population history. Proceedings of the National Academy of Sciences of the United States of America, $87(2), 836-840$.

Zerabruk, M., Bennewitz, J., Kantanen, J., Olsaker, I., \& Vangen, O. (2007). Analysis of genetic diversity and conservation priorities for six north Ethiopian cattle breeds. Journal of Animal Breeding and Genetics, 124(4), 236-241. 